\title{
Lactobacillus hayakitensis sp. nov., isolated from intestines of healthy thoroughbreds
}

\author{
Correspondence \\ Hidetoshi Morita \\ morita@azabu-u.ac.jp
}

\author{
Hidetoshi Morita, ${ }^{1}$ Chiharu Shiratori, ${ }^{1}$ Masaru Murakami, ${ }^{1}$ Hideto Takami, ${ }^{2}$ \\ Yukio Kato, ${ }^{1}$ Akihito Endo, ${ }^{3}$ Fumihiko Nakajima, ${ }^{4}$ Misako Takagi, ${ }^{5}$ \\ Hiroaki Akita, ${ }^{4}$ Sanae Okada $^{3}$ and Toshio Masaoka ${ }^{1}$
${ }^{1}$ School of Veterinary Medicine, Azabu University, 1-17-71 Fuchinobe, Sagamihara, Kanagawa 229-8501, Japan \\ ${ }^{2}$ Microbial Genome Research Group, Japan Agency of Marine-Earth Science and Technology, \\ 2-15 Natsushima, Yokosuka, Kanagawa 237-0061, Japan \\ ${ }^{3}$ Nodai Culture Collection Center, Department of Brewing, Tokyo University of Agriculture, \\ 1-1-1 Sakuragaoka, Setagaya, Tokyo 156-8502, Japan \\ ${ }^{4}$ Northern Farm, 275 Hayakita-genbu, Abira-cho, Yufutsu-gun, Hokkaido 059-1432, Japan \\ ${ }^{5}$ Clossfield-Bio Inc., 1-1-20, Higashi Nihonbashi, Chuo, Tokyo 103-0004, Japan
}

Lactobacilli are important members of healthy gastrointestinal tracts of mammals and humans, and some of them are frequently administered as probiotics for their beneficial roles in mammalian and human health. However, there have only been a few studies on the Lactobacillus flora of thoroughbred gastrointestinal contents by using the culturing method (Mitsuoka \& Kaneuchi, 1977; Morotomi et al., 2002). In our study, we isolated the following lactobacilli present in the intestinal

The GenBank/EMBL/DDBJ accession number for the 16S rRNA gene sequence of strain $\mathrm{KBL} 13^{\top}$ is $\mathrm{AB} 267406$.

Trees showing the phylogenetic relationship, based on the 16S rRNA gene sequence, of the isolate in comparison to species of the Lactobacillus salivarius phylogenetic group constructed by the maximum-parsimony and maximum-likelihood methods are available with the online version of this paper. tract of healthy thoroughbreds: Lactobacillus gasseri, Lactobacillus johnsonii, Lactobacillus ruminis, Lactobacillus reuteri, Lactobacillus salivarius, Lactobacillus crispatus and Lactobacillus agilis. These species are well-known species isolated from mammalian gastrointestinal tracts. Lactobacillus equi was also found during our study, which is a dominant and indigenous species in equine gastrointestinal tracts (Morotomi et al., 2002). As part of a study on the intestinal microbiota in thoroughbreds, two strains, $\mathrm{KBL}^{\mathrm{T}}{ }^{\mathrm{T}}$ and GBL13, were isolated from different thoroughbreds. A polyphasic taxonomic study of these strains was performed using phenotypic characterization and phylogenetic as well as genetic methods; the results obtained by using these methods consistently revealed the isolates, $\mathrm{KBL}^{\mathrm{T}}{ }^{\mathrm{T}}$ and GBL13, to represent a novel Lactobacillus species, from intestines of thoroughbreds, for which the name Lactobacillus hayakitensis sp. nov. is proposed. 
Bacterial strains, $\mathrm{KBL}_{1} 3^{\mathrm{T}}$ and GBL13, were isolated from fresh faeces of different healthy thoroughbreds of the same farm where they were born in Hokkaido, Japan. The fresh faeces of each thoroughbred were transferred under anaerobic conditions by AnaeroPack (Mitsubishi Gas Chemical) at $4{ }^{\circ} \mathrm{C}$ to our laboratory within $24 \mathrm{~h}$. The initial processing and subsequent weighing and dilution of the specimens were carried out under anaerobic conditions. Each dilution was then spread on to $\mathrm{BL}$ agar plates (Eiken Chemical) and incubated anaerobically at $37^{\circ} \mathrm{C}$ for 2 days. All further cultivation was performed at $37^{\circ} \mathrm{C}$ in ABCM broth (Eiken Chemical). The $16 \mathrm{~S}$ rRNA gene sequences of the isolates were determined as described previously (Endo \& Okada, 2005). The 1484 bp of the $16 \mathrm{~S}$ rRNA gene sequence of $\mathrm{KBL}^{\mathrm{T}}{ }^{\mathrm{T}}$ was consistent with those of GBL13. DNA-DNA hybridization was carried out by using the microdilution-well technique, with photobiotin for labelling of the DNA (Ezaki et al., 1989). KBL13 ${ }^{\mathrm{T}}$ and GBL13 shared high levels of DNA-DNA relatedness (99.5$100.0 \%)$. The closest known relatives of the isolates were determined by performing database searches, and the sequences of closely related species were retrieved from the DDBJ database. Multiple alignments of the sequences were carried out with the CLUSTAL_X program, version 1.18 (Thompson et al., 1997). Distance matrices for the aligned sequences were calculated by using the two-parameter method of Kimura (1980). The neighbour-joining method was used to construct a phylogenetic tree (Saitou \& Nei, 1987). The robustness of individual branches was estimated by using bootstrapping with 1000 replicates (Felsenstein, 1985). Phylogenetic trees were also constructed by using the maximum-likelihood (Cavalli-Sforza \& Edwards, 1967) and maximum-parsimony (Kluge \& Farris, 1969) methods with PHYLIP version 3.65 (Felsenstein, 2005).

In a neighbour-joining dendrogram created based on the sequence of $\mathrm{KBL}_{1} 3^{\mathrm{T}}$ and sequences from the GenBank database, the phylogenetic position of $\mathrm{KBL} 3^{\mathrm{T}}$ was determined. KBL13 ${ }^{\mathrm{T}}$ was placed within the L. salivarius phylogenetic group (Canchaya et al., 2006) and was most closely related to $L$. salivarius, Lactobacillus aviarius, Lactobacillus saerimneri and Lactobacillus acidipiscis as shown in Fig. 1. Recently, on the basis of a polyphasic analysis, Li et al. (2006) indicated that L. salivarius subsp. salivarius and $L$. salivarius subsp. salicinicus did not merit separate subspecies status. As the information of the physiological characteristics of L. salivarius JCM 1150 is available to us (previously described as L. salivarius subsp. salicinicus JCM 1150), the physiological characteristics of $\mathrm{KBL}^{\mathrm{T}}{ }^{\mathrm{T}}$ and GBL13 were compared with those of $L$. salivarius JCM $1231^{\mathrm{T}}$ (=ATCC $11741^{\mathrm{T}}$; AF089108) and JCM 1150 as shown in Table 1. L. salivarius JCM $1231^{\mathrm{T}}$ and JCM 1150, L. aviarius subsp. aviarius JCM $5666^{\mathrm{T}}$ and $L$. aviarius subsp. araffinosus JCM $5667^{\mathrm{T}}$ used in the study were obtained from the Japan Collection of Microorganisms. A high similarity of $96.0 \%$ (1425/ $1484 \mathrm{bp}$ ) was observed in the $16 \mathrm{~S}$ rRNA gene sequences of $\mathrm{KBL}_{1} 3^{\mathrm{T}}$ and L. salivarius $\mathrm{JCM} 1231^{\mathrm{T}}$. Identical tree topologies were obtained by using the maximum-likelihood and maximum-parsimony methods (see Supplementary Figs S1 and S2 available in IJSEM Online).

The DNA G + C content was determined by hydrolysing the DNA enzymically and quantifying the nucleosides by HPLC according to the method of Ezaki et al. (1990). The DNA $\mathrm{G}+\mathrm{C}$ content of $\mathrm{KBL}_{13}{ }^{\mathrm{T}}$ and GBL13 were 34.3 and $34.8 \mathrm{~mol} \%$, respectively. The DNA G $+\mathrm{C}$ content of their closest relatives, L. salivarius JCM $1231^{\mathrm{T}}$ and $L$. aviarius subsp. araffinosus JCM $5667^{\mathrm{T}}$ was 34.7 and $41.3 \mathrm{~mol} \%$, respectively. The DNA G $+\mathrm{C}$ content of KBL13 ${ }^{\mathrm{T}}$ was found to be within the range of $32.0-55.0 \mathrm{~mol} \%$, which is the range reported for Lactobacillus species (Kandler \& Weiss, 1986).

The sugar fermentation patterns were determined using the API 50CH system (bioMérieux) according to the

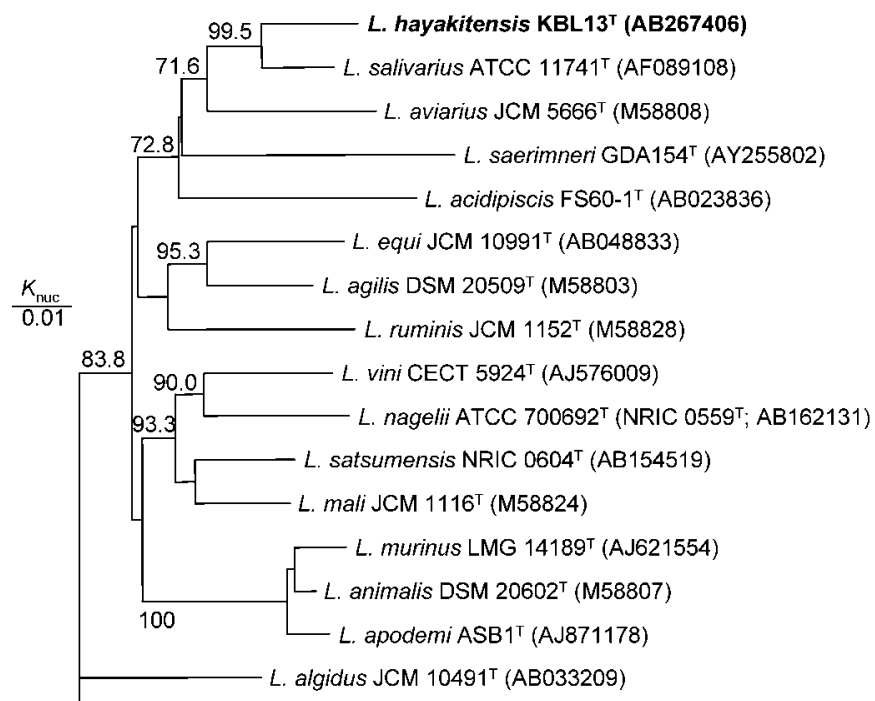

L. delbrueckii ATCC 9649 (AY050172)
Fig. 1. Phylogenetic relationship of the isolate to the species of the $L$. salivarius phylogenetic group based on the 16S rRNA gene sequences is shown. The tree was constructed by the neighbour-joining method. $L$. delbrueckii ATCC $9649^{\top}$ was used as an outgroup. Bootstrap percentages above $70.0 \%$ are given at the branching points. 
Table 1. Physiological characteristics of strains $\mathrm{KBL} 13^{\top}$ and $\mathrm{GBL} 13$ and type strains of the closely related Lactobacillus species

Strains: 1, KBL13 ${ }^{\mathrm{T}}$; 2, GBL13; 3, L. salivarius JCM 1231 ${ }^{\mathrm{T}}$; 4, L. salivarius JCM 1150; 5, L. aviarius subsp. aviarius JCM 5666 ${ }^{\mathrm{T}}$ (Fujisawa et al. 1984); 6 , L. aviarius subsp. araffinosus JCM $5667^{\mathrm{T}}$ (Fujisawa et al. 1984). +, Positive; -, negative; w, weakly positive; ND, no data available. All strains were positive for the following characteristics: fermentation of glucose, fructose, mannose, maltose, sucrose; growth in MRS broth at $37{ }^{\circ} \mathrm{C}$ and no growth in MRS broth at $15{ }^{\circ} \mathrm{C}$. The DNA G $+\mathrm{C}$ contents were determined by HPLC.

\begin{tabular}{|c|c|c|c|c|c|c|}
\hline Characteristic & 1 & 2 & 3 & 4 & 5 & 6 \\
\hline Lactic acid isomers & $\mathrm{L}$ & $\mathrm{L}$ & Mainly L & Mainly L & $\mathrm{DL}$ & DL \\
\hline \multicolumn{7}{|l|}{ Fermentation of: } \\
\hline Galactose & - & - & + & + & + & - \\
\hline Rhamnose & - & - & + & - & ND & ND \\
\hline Sorbitol & - & - & + & + & ND & ND \\
\hline $\mathrm{N}$-Acetyl-D-glucosamine & + & - & + & + & $\mathrm{ND}$ & $\mathrm{ND}$ \\
\hline Amygdalin & $\mathrm{W}$ & $\mathrm{W}$ & - & - & - & - \\
\hline Arbutin & + & - & - & + & ND & $\mathrm{ND}$ \\
\hline Aesculin & + & + & - & + & + & - \\
\hline Salicin & + & + & - & + & + & - \\
\hline Cellobiose & + & + & - & - & + & - \\
\hline Lactose & - & - & + & + & - & - \\
\hline Melibiose & - & - & + & + & + & - \\
\hline Trehalose & - & - & + & + & + & + \\
\hline Raffinose & $\mathrm{W}$ & - & + & + & + & - \\
\hline Gentiobiose & + & + & - & - & ND & ND \\
\hline Growth on MRS medium at $45{ }^{\circ} \mathrm{C}$ & + & + & + & + & ND & ND \\
\hline DNA G + C content $(\mathrm{mol} \%)$ & 34.3 & 34.8 & 34.7 & ND & 38.7 & 41.3 \\
\hline Peptidoglycan type & Lys-Asp & Lys-Asp & Lys-Asp & Lys-Asp & Lys-Asp & Lys-Asp \\
\hline
\end{tabular}

manufacturer's instructions. The results were recorded after $48 \mathrm{~h}$ at $37^{\circ} \mathrm{C}$. The isomer of lactic acid produced from glucose was determined by using an F-kit (D-lactic acid/L-lactic acid; Roche Diagnostics Corporation). Other biochemical tests, such as those on motility, growth at a fixed temperature and gas production from glucose, were performed by using the methods described by Mitsuoka (1969). Table 1 shows the characteristics most useful in distinguishing the strains studied from closely related lactobacilli. Since KBL13 ${ }^{\mathrm{T}}$ and GBL13 were found to be the same species, $\mathrm{KBL}^{\mathrm{T}}{ }^{\mathrm{T}}$ was used as a representative strain in the experiments described below.

DNA-DNA hybridization analyses (Ezaki et al., 1989) were performed, including those for the two most closely related species, L. salivarius JCM $1231^{\mathrm{T}}$ and JCM 1150, and $L$. aviarius subsp. araffinosus JCM $5667^{\mathrm{T}}$, based on the $16 \mathrm{~S}$ rRNA gene sequence analysis. DNA-DNA relatedness values between $\mathrm{KBL}_{13}{ }^{\mathrm{T}}$ and $L$. salivarius JCM $1231^{\mathrm{T}}$ and JCM 1150, and L. aviarius subsp. araffinosus JCM $5667^{\mathrm{T}}$ were $14.2,12.1$ and $7.9 \%$, respectively. These values are well below the threshold of $70.0 \%$ that is suggested for species delineation (Stackebrandt \& Goebel, 1994), indicating that strain $\mathrm{KBL}_{1} 3^{\mathrm{T}}$ represents a separate genomic species. Analysis by high-performance thin-layer chromatography showed that meso-diaminopimelic acid was not contained in the peptidoglycan of the strain $\mathrm{KBL} 13^{\mathrm{T}}$, and an analysis, by ultraperformance liquid chromatography according to the methods described by Komagata \& Suzuki (1987), of the cell wall composition revealed the
Lys-Asp peptydoglycan type in the presence of Lys, Glu, Ala and Asp.

DNA-DNA relatedness showed a clear separation of strain $\mathrm{KBL} 13^{\mathrm{T}}$ from its phylogenetic relatives, it is considered that the strain studied represents a novel species belonging to the genus Lactobacillus, for which the name Lactobacillus hayakitensis sp. nov. is proposed.

\section{Description of Lactobacillus hayakitensis sp. nov.}

Lactobacillus hayakitensis (ha.ya.ki.ten'sis. N.L. masc. adj. hayakitensis of Hayakita, which is the name of the area where the bacterium was originally isolated).

Cells are Gram-positive, 3.0-5.0 $\mu \mathrm{m}$ long and 1.0-1.5 $\mu \mathrm{m}$ wide, non-motile and non-spore-forming rods. They occur singly or in pairs. Colonies are small $(1.5 \mathrm{~mm})$, circular to slightly irregular, convex, with a smooth to rough surface, and white when grown on MRS agar. The optimum growth temperature is $37^{\circ} \mathrm{C}$. Strain $\mathrm{KBL} 13^{\mathrm{T}}$ is not able to grow in $4.5 \% \mathrm{NaCl}$ and at $15{ }^{\circ} \mathrm{C}$, but grows in $3.0 \% \mathrm{NaCl}$ and at $45{ }^{\circ} \mathrm{C}$. Cells are catalase-negative. Glucose is metabolized homofermentatively and lactate is the sole final product. Strain $\mathrm{KBL} 13^{\mathrm{T}}$ produces $\mathrm{L}(+)$-lactic acid. Acid is produced from glucose, fructose, mannose, mannitol, $N$-acetyl-Dglucosamine, arbutin, aesculin, salicin, cellobiose, maltose, sucrose and gentiobiose. Amygdalin and raffinose are weakly fermented. In this species, some strains cannot ferment $N$-acetyl-D-glucosamine, arbutin and raffinose. The DNA G + C content of the type strain is $34.3 \%$, and 
the cell wall composition of the strain exhibits the Lys-Asp peptydoglycan type.

The type strain, $\mathrm{KBL}^{2}{ }^{\mathrm{T}}\left(=\mathrm{JCM} 14209^{\mathrm{T}}=\mathrm{DSM} 18933^{\mathrm{T}}\right)$, was isolated from the faeces of a thoroughbred.

\section{Acknowledgements}

We would like to thank Ms Sayuri Nagata of the Laboratory of Food Science, Azabu University, for her technical assistance. We also wish to thank the Private University Scientific Foundation for financial support.

\section{References}

Canchaya, C., Claesson, M. J., Fitzgerald, G. F., van Sinderen, D. \& O'Toole, P. W. (2006). Diversity of the genus Lactobacillus revealed by comparative genomics of five species. Microbiology 152, 3185-3196.

Cavalli-Sforza, L. L. \& Edwards, A. W. F. (1967). Phylogenetic analysis models and estimation procedures. Am J Hum Genet 19, 233-257.

Endo, A. \& Okada, S. (2005). Lactobacillus satsumensis sp. nov., isolated from mashes of shochu, a traditional Japanese distilled spirit made from fermented rice and other starchy materials. Int J Syst Evol Microbiol 55, 83-85.

Ezaki, T., Hashimoto, Y. \& Yabuuchi, E. (1989). Fluorometric deoxyribonucleic acid-deoxyribonucleic acid hybridization in microdilution wells as an alternative to membrane filter hybridization in which radioisotopes are used to determine genetic relatedness among bacterial strains. Int J Syst Bacteriol 39, 224-229.

Ezaki, T., Saidi, S. M., Liu, S. L., Hashimoto, Y., Yamamoto, H. \& Yabuuchi, E. (1990). Rapid procedure to determine the DNA base composition from small amounts of Gram-positive bacteria. FEMS Microbiol Lett 67, 127-130.

Felsenstein, J. (1985). Confidence limits on phylogenies: an approach using the bootstrap. Evolution 39, 783-791.

Felsenstein, J. (2005). PHYLIP (phylogeny inference package), version 3.65. Distributed by the author. Department of Genome Sciences, University of Washington, Seattle, USA.
Fujisawa, T., Shirasaka, S., Watanabe, J. \& Mitsuoka, T. (1984). Lactobacillus aviaries sp. nov.: a new species isolated from the intestine of chickens. Syst Appl Microbiol 5, 414-420.

Kandler, O. \& Weiss, N. (1986). The genus Lactobacillus. In Bergey's Manual of Systematic Bacteriology, vol. 2, pp. 1208-1234. Edited by P. H. A. Sneath, N. S. Mair, M. E. Sharpe \& J. G. Holt. Baltimore: Williams \& Wilkins.

Kimura, M. (1980). A simple method for estimating evolutionary rates of base substitutions through comparative studies of nucleotide sequences. J Mol Evol 16, 111-120.

Kluge, A. G. \& Farris, J. S. (1969). Quantitative phyletics and the evolution of the anurans. Syst Zool 18, 1-32.

Komagata, K. \& Suzuki, K. (1987). Lipid and cell wall analysis in bacterial systematics. Methods Microbiol 19, 161-207.

Li, Y., Raftis, E., Canchaya, C., Fitzgerald, G. F., van Sinderen, D. \& O'Toole, P. W. (2006). Polyphasic analysis indicates that L. salivarius subsp. salivarius and $L$. salivarius subsp. salicinicus do not merit separate subspecies status. Int J Syst Evol Microbiol 56, 2397-2403.

Mitsuoka, T. (1969). Vergleichende Untersuchungen uber die Lactobazillen aus den Faeces von Menschen, Schweinen und Huhnern. Zentralbl Bakteriol [Orig] 210, 32-51 (in German)

Mitsuoka, T. \& Kaneuchi, C. (1977). Ecology of the bifidobacteria. Am J Clin Nutr 30, 1799-1810.

Morotomi, M., Yuki, N., Kada, Y., Kushiro, A., Shimazaki, T., Watanabe, K. \& Yuyama, T. (2002). Lactobacillus equi sp. nov., a predominant intestinal Lactobacillus species of the horse isolated from faeces of healthy horses. Int J Syst Evol Microbiol 52, 211-214.

Saitou, N. \& Nei, M. (1987). The neighbor-joining method: a new method for reconstructing phylogenetic trees. Mol Biol Evol 4, 406-425.

Stackebrandt, E. G. \& Goebel, B. M. (1994). Taxonomic note: a place for DNA-DNA reassociation and $16 \mathrm{~S}$ rRNA sequence analysis in the present species definition in bacteriology. Int $J$ Syst Bacteriol 44, 846-849.

Thompson, J. D., Gibson, T. J., Plewniak, F., Jeanmougin, F. \& Higgins, D. G. (1997). The CLUSTAL_X windows interface: flexible strategies for multiple sequence alignment aided by quality analysis tools. Nucleic Acids Res 25, 4876-4882. 